\title{
Ján Kadár
}

\author{
By Peter Hames
}

Spring 2013 Issue of KINEMA

When The Shop on Main Street (Obchod na korze, 1965) won the Best Foreign Film Oscar in 1966, it marked the first ever for Czechoslovakia and the decisive breakthrough in international awareness of the Czechoslovak New Wave. Yet its co-directors, Ján Kadár and Elmar Klos, were not part of the younger generation that emerged from the Prague Film School in the 1960s. Klos had begun his career before the Second World War and Kadár made his debut in 1945. After the success of The Shop on Main Street, they completed only one more film before the Soviet suppression of the Prague Spring brought an end to their partnership. In 1968-69, they shot Touha zvaná Anada (Adriftaka Desire is Called Anada), released in 1971, the only Czechoslovak-US co-production to be shot in the "socialist" era.

Kadár emigrated to the United States where he shot an adaptation of Bernard Malamud's The Angel Levine (1970), featuring Harry Belafonte and Zero Mostel, before making Lies My Father Told Me (1975) in Canada, which won a Golden Globe award as Best Foreign Film as well as an Oscar nomination for its screenplay. In all Kadár made seven films in North America before his death in 1979. His early death (at 61) has led to his work being somewhat overshadowed by that of younger Czech emigrants such as Miloš Forman and Ivan Passer. In Czechoslovakia, his name could not be mentioned for 20 years while foreign distributors of The Shop on Main Street were instructed to incinerate their release copies. As Antonín Liehm put it in 1974: "In Prague today they are unwriting history. The people did not exist. The films were not produced. Nothing happened".

Václav Macek's new book suggests that it's time to re-evaluate Kadár's work in both its Czech and Slovak and North American contexts. Born to Hungarian Jewish parents in 1918, Kadár was raised in the town of Rožňava, which became part of Czechoslovakia in the same year. His background was bilingual (Slovak and Hungarian) and he initially set out to follow his father in the law profession by enrolling for a Law degree in Prague in 1936. However, his love for film won out when he enrolled in a film production course in the Slovak capital of Bratislava in 1938. The course had been initiated by the Czech photographer, ethnographer, and film director, Karel Plicka who, after the Second World War, became the first Dean of the Prague Film School FAMU.

After the creation of the Slovak independent state in 1939, Kadár left for Hungary, where conditions for Jews were initially less severe. In 1940, he was required to report to a labour camp from which he eventually escaped in 1944. "I was raised in a way that I never felt a Jew in religious or ethnic terms. I actually should say that I did not know I was a Jew until Hitler spoke of it". With the exception of his brother, all of Kadár's family died in Auschwitz.

In 1945, Kadár returned to Czechoslovakia and worked for the Slovak film company, directing two documentaries Na troskách vyrastá život (Life is Rising from the Ruins, 1945) and Sú osobne zodpovedni (They Are Personally Responsible, 1946), an attack on the Fascist regime in wartime Slovakia. He met the Czech director, Elmar Klos, in 1946 and was offered work in Prague, where he attended FAMU for one year (1946-47) and worked as assistant director on a number of Czech features. His first feature film offer came from the nascent Slovak feature film industry in 1949.

Katka (Cathy, 1949) was conceived within the newly applied constraints of Socialist Realism (the Communist takeover dated from February 1948) and its story of a country girl who goes to work in a textile factory met the then-propaganda requirements of the government. However, its original emphases underwent some changes at the hands of the Czech writer, Vratislav Blažek, known for his work with Divadlo satiry (The Theatre of Satire), who had the distinction of having written the first play banned under Communism.

It was the first of three collaborations with Kadár, and the film was transformed into a comedy about a young girl working in a factory producing pantyhose. Despite conforming to broad guidelines and a success with audiences, it was condemned as an ideological failure in the Slovak press. Czech reviews were more positive and he returned to the Barrandov studios in Prague in 1950, which were to provide the base for all his subsequent films in Czechoslovakia. It also marked the beginning of his long collaboration with Elmar 
Klos, and they were to take co-direction and writing credits on all their subsequent Czech films, although also working with other writers on screenplays.

Klos, one of the architects of the nationalised industry, who was sacked from Barrandov in 1951, was brought back to work on Kadár's new film Únos (Kidnapped, 1952). Made at the height of the Stalinist show trials of the early 1950s, it was little more than a Cold War thriller about American spies hijacking a plane from Ostrava to West Germany. It was based on a true event in which three Dakotas had been flown simultaneously to the West. Of the 85 persons on board, 27 had applied for political asylum. While the film in no way deviated from political requirements, Kadár treated it as an adventure story - a thriller more or less a stylistic exercise. Nonetheless, it was accused of "bourgeois objectivism" and, had not been for the intervention of Vsevolod Pudovkin (then in Prague "hiding from Stalin" according to Vojtěch Jasný), it would not have been released.

Both Kadár and Klos were Left intellectuals, members of the Communist Party, and dedicated to the building of a new society, but their 'difficulties' cast considerable light not only on the desire for in- dependent thought but also on the evolution and struggles occurring within the constraints of Socialist Realism. Their joint credits recall that of another film partnership, that of Michael Powell and Emeric Pressburger. Interestingly, Pressburger was born in the town of Miskolc (birthplace of Kadár's father) to a family originating in Bratislava (Pressburg). The collaboration between Kadár and Klos seems very similar with the more mercurial Kadár responsible for directing and Klos having a firm hand on production and collaborating on the screenplay - but with a clear creative and critical input. As Billy Wilder once said, the best collaboration was usually between people of opposite temperament.

They returned to comedy with two further films based on the work of Blažek, Hudba z Marsu (Music from Mars, 1955) and Tři prání (Three Wishes, 1958). According to Macek, Blažek maintained the tradition of the Theatre of Satire in both Cirkus bude (There Will Be a Circus, Oldřich Lipský, 1954) and Music from Mars, describing his work as being as extraordinary as that of the Liberated Theatre of Jiří Voskovec and Jan Werich in the 1930s. The story of Music from Mars focused on the Mars furniture factory, where the local chairman decides to put together a factory band to comply with the new requirements for 'worker care'. Their first film in colour, it was essentially a musical comedy and featured a number of pre-war comedy stars - Oldřich Nový, Jaroslav Marvan, Jan Werich. Its criticism of bureaucracy led to a ban prior to its release, and the withdrawal of positive reviews. A film in which laughter came before ideology, it was eventually released on the instructions of the then-President, Antonín Zápotocký.

The screenplay of Three Wishes went into production without official approval and was one of three films to be banned in the late 1950s, remaining so until 1963. Described as a film that was not quite a satire, nor fairy-tale, or morality play, it told the traditional story of a man granted three wishes, but its criticism of individual morality and of society was to prove too radical. The central character gains from the successful granting of his wishes, but is offered the opportunity of a fourth wish - to speak up publicly in defence of a colleague - in exchange for giving up the material benefits of the first three. It exposed a world of social corruption and hypocrisy far from the ideal society supposedly being created. Kadár and Klos were banned from the studios until 1963.

Although committed to 'progressive' ideas, the work of Kadár and Klos consistently transcended the demands of simplistic ideology, both criticising and satirising the system. A little known film from the late 1950s Tam na konečné (At the Terminus / The House at the Terminus, 1957) showed the ways in which the bounds of Socialist Realism could be made flexible. Based on stories by Ludvík Aškenazy, it could be contained within the category of "the poetry of everyday life". Aškenazy's stories of ordinary people were nonetheless suffused in melancholy and its themes of a drunkard searching for custody of his daughter and a mother waiting for a wrongly imprisoned husband were certainly outside the bounds of more rigid criteria. It also marked the feature debut of composer Zdeněk Liška, who was to become their regular collaborator. Already, he was 'designing' the soundtrack as well as writing the music.

Although Kadár was now working in Prague, the influence of Slovakia remained strong. Two of his most significant films Smrt si řiká Engelchen (Death is Called Engelchen, 1963) and The Shop on Main Street were both based on the work of Slovak writers, both The Shop on Main Street and Adrift were shot in Slovakia, and he regularly used Slovak actors (e.g. Vlado Müller in Death is Called Engelchen and Obžalovaný (The 
Defendant/The Accused, 1964).

Death is Called Engelchen, adapted from the novel by Ladislav Mňačko, is a powerful account of the partisan struggle against the Germans in Moravia, but also an unorthodox portrait of the war. A wounded partisan, Pavel, recalls the brutality, compromise, and suffering of wartime activities from his hospital bed, suffering all the while from hallucinations and doubts. A Jewish theme makes its appearance through his relationship with Marta, a Jewish undercover agent who supplies information to the partisans while working as a prostitute to the SS. The value of Pavel's actions and of heroic myths is questioned while Marta forfeits the possibility of a normal life. Despite its questioning approach and a flashback structure reminiscent of Hiroshima mon Amour (1959), the film was highly praised both in the Soviet bloc and internationally, most notably winning a Gold Prize at Moscow and state awards in Czechoslovakia.

Their next film, The Accused, again courted controversy. In some ways reminiscent of Sidney Lumet's Twelve Angry Men (1957), it's the story of a trial and based on a true story. Kudrna (Vlado Müller), a workerdirector put in charge of the construction of a power plant after February 1948, is discovered to have given bonuses to workers to complete the work on time. He is accused of fraud, and put on trial. In reality, the real Kudrna accepted a symbolic sentence of three months but in the film, he rejects the verdict and returns to jail. The film, of course, had a broader reference to the trials of the 1950s, and was an indictment of a system that punished the innocent. Anticipating a negative response, Kadár and Klos, in fact, shot two alternative endings. In fact, the film marked a breakthrough, not only winning the Grand Prix at Karlovy Vary, but stimulating discussion throughout the Soviet bloc, and joining the early films of the New Wave in their international breakthrough.

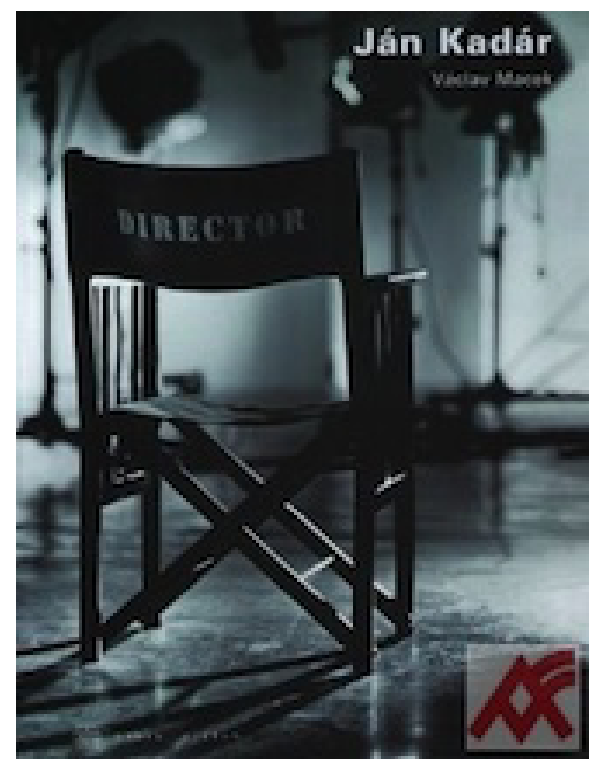

Figure 1: JÁN KADÁR. By Václav Macek. đ Bratislava: FOTOFO Central European House of Photography, Slovak Film Institute, Academy of Performing Arts, 2011. 370pp. Paperback.

With The Shop on Main Street, from the story by Ladislav Grosman, Kadár returned to Slovakia and to the realities of his own wartime experience. There was no interference on the production (Kadár described the years 1964-68 as a period of "sweet anarchy" that provided the best conditions for film making anywhere in the world). The story is well known. An old deaf Jewish woman, Mrs Lautmannová (Ida Kamińska), who owns a small shop selling buttons, is allocated an Aryan controller, Tono Brtko (Jozef Kroner) under the anti-Jewish laws of the wartime state. However, Tono is a wellmeaning carpenter whose only wish is to survive, stay out of trouble, and get on with his neighbours. His compromises lead him on a path to virtual collusion and her accidental death when he hides her from the forced evacuation of the Jewish community.

It was a grim moral fable with tragic-comic elements, revealing both the everyday and ideological faces of Fascism. Significantly, the film marked the first of three collaborations with Kamińska, a leading actress in 
the Polish Yiddish theatre, and who subsequently followed Kadár to the United States. She was taught the East Slovak dialect by assistant director Juraj Herz (described by Kadár as his alter ego). Herz, like Kadár, as a Slovak Jew, had experienced the realities of the Fascist regime in Slovakia, and had been imprisoned in Ravensbrück.

After the Soviet invasion, Kadár left for Vienna, and shot his first English language film, The Angel Levine (February-May 1969), completing Adrift in September 1969. Of Kadár's former collaborators, Blažek emigrated to West Germany, Mňačko to Austria, Grosman to Israel, and Aškenazy to West Germany and Italy. Klos remained in Czechoslovakia, his career as a film maker effectively at an end.

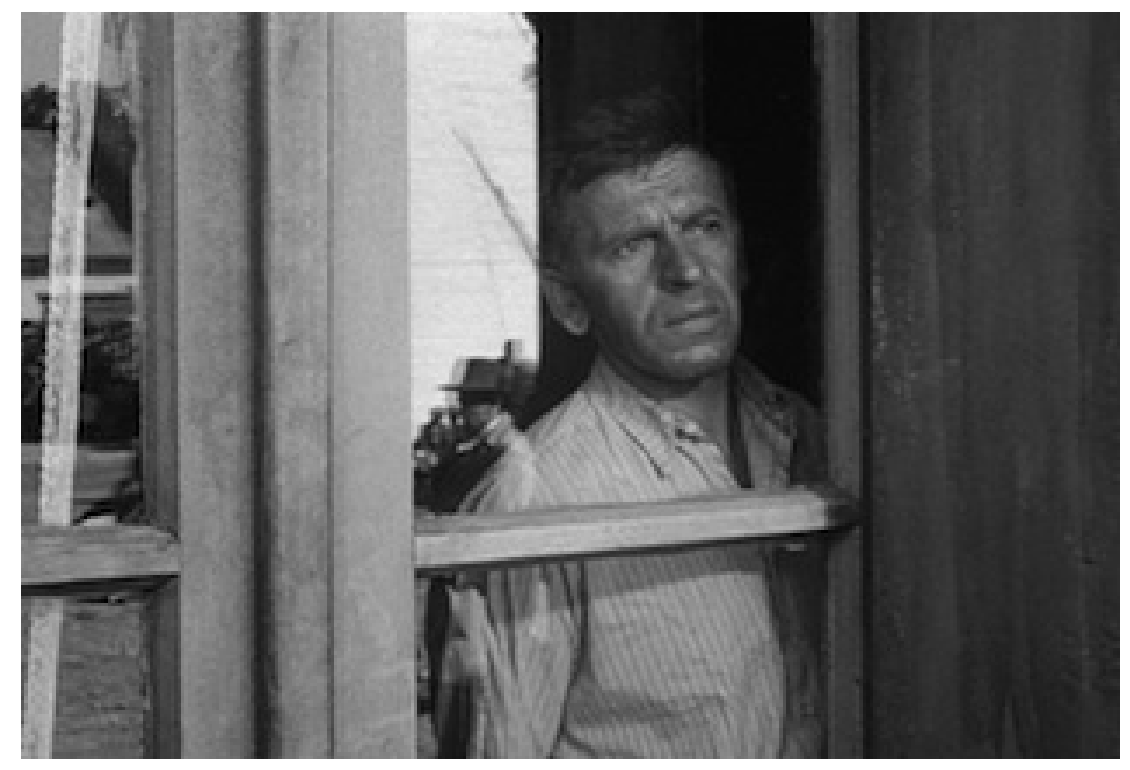

Figure 2: Jozef Kroner in The Shop on Main Street (Obchod na korze, 1965)

Adrift was significantly shortened in its final montage and received its Czech and US premieres in 1971. With Adrift, described by Macek as Kadár's most personal film, he worked with the Hungarian writer and director Imre Gyöngyössy, whose poetic contribution should not be ignored, particularly given his contribution to the final montage. It's based on a Hungarian novel about a beautiful girl, Anada (Paula Pritchett), rescued from drowning in the Danube. Pritchett was deliberately cast as an enigma, almost a fantasy. A fisherman, János, played by Yugoslav actor Rade Marković, falls in love with Anada, and his wife becomes ill. From this basic triangle drama, Kadár and Klos create a film of considerable poetic beauty and fluidity. János meets three men who begin to question him (Jozef Kroner, Vlado Müller, Gustav Valach), acting as a kind of Greek chorus and promoting three different versions of the story.

While The Angel Levine was made with an unfinished screenplay and suffered from certain other compromises - Zdeněk Liška's soundtrack, for instance, was redone - it had, according to Macek, a contemporary relevance to ethnic tensions between black and Jewish communities in New York and accusations of black anti-Semitism. Malamud's original story tells of a Jewish tailor (Zero Mostel) whose faith is tested when he is visited by a black angel, Alexander Levine (Harry Belafonte), who claims he has been sent by God. Ida Kamińska was cast in the role of Mostel's wife. The original story ended with a miracle and a happy ending. Kadár's ends in tragedy.

After shooting a television adaptation of Stephen Crane's The Blue Hotel (1974) for US television, Kadár made two films in Canada, the first, Mandelstam's Witness (1975), based on Nadezhda Mandelstam'sHope Against Hope and featuring Ida Kamińska in the main role. Described as the Canadian Broadcasting System's most striking success of the year, it apparently received only one screening and has been lost to view. Lies My Father Told Me (1975), based on Ted Allan's screenplay about a Jewish community in 1920s Montreal, seemed likely to prove his breakthrough in North America. Besides its US awards, it was hailed by some critics as the most important Canadian film to date, achieving a breakthrough in international markets that 
was then rare for Canadian cinema. In atmosphere and sophistication, it is perhaps the closest to the Czech tradition.

Kadár was, of course, now working within a new production system, without the security and support of his creative partner, Elmar Klos. According to Macek, he never gave up on the plans that he and Klos had for the filming of Karel Čapek's seminal science fiction work, War with the Newts, and he was also in contact with Mňačko regarding a possible film version of his political novel Ako chutí moc (The Taste of Power). Kadár's film for CBS, The Case Against Milligan (1975), a US legal story from the 1860s, in which Lincoln's attempt to suspend the Constitution in order to sentence a southern lawyer to death by court martial is overruled by the Supreme Court, was linked to a number of issues discussed with Mňačko in connection with The Taste of Power.

In 1975, Kadár joined the American Film Institute as filmmaker in residence, but completed two further features before his death, both made for television and both continuing the political commitment of his years in Czechoslovakia. The Other Side of Hell (1978), was based on the true story of William J. Thomas, who spent nine years in the psychiatric ward of a prison hospital before escaping. He decided to tell his story after seeing Miloš Forman's One Flew Over the Cuckoo's Nest (1975). In the film version, Frank Dole (Alan Arkin) opts for voluntary mental health treatment and ends up exposing the brutality of the system. Constructed as a three hour film in ten 'chapters', its low-key 'documentary' style differs from that of Forman, presenting its central character as fundamentally an average American. It received a positive critical response.

With Freedom Road (1979), he adapted Howard Fast's seminal novel (1944) about a black Civil War hero, Gideon Jackson, who subsequently becomes a senator. Unfortunately, Muhammad Ali was cast in the main role - a condition for raising the money. His performance was condemned as wooden and the film as being rather like a history lesson. Although Kadár devised strategies for minimising Ali's acting problems he was unable to participate in post production or the final editing. Working with a large budget, the film was shown in two parts, running a total of 185 minutes, but cut down to 89 minutes for feature release. Fast was approving of the film's first half but considered Ali's acting in the second half to be something of a 'disaster'. Nonetheless, the film is still considered an important landmark in the portrayal of black history in cinema.

Although Kadár's work for television lost him mainstream critical attention, it still marks a significant achievement - and The Blue Hotel, The Other Side of Hell, and Freedom Road (albeit as a truncated cinema release) did reach out internationally. Who knows what might have been - after all, according to Macek, Kadár was at various times offered The Confession (filmed by Costa-Gavras),Fiddler on the Roof, and The Godfather.

Kadár is remembered by most as the director of what is widely regarded as one of the best films about the Holocaust. Yet, it is also true that Holocaust films almost became a genre in the former Czechoslovakia. They include Alfréd Radok's Daleká cesta (The Long Journey, 1949), Jiří Weiss's Romeo, Julie a tma (Romeo, Juliet and Darkness, 1959), and a succession of films adapted from the novels and stories of Arnošt Lustig: Transport $z$ ráje (Transport from Paradise, Zbyněk Brynych, 1962), Démanty noci (Diamonds of the Night, Jan Němec, 1964) - Agnieszka Holland's candidate for the best Holocaust film, and Modlitba pro Kateřinu Horovitzovou ( $A$ Prayer for Katerina Horovitzová (1965) and Dita Saxová (1967), both directed by Antonín Moskalyk. Juraj Herz, who was born in Eastern Slovakia, was assistant director on both Transport from Paradise and The Shop on Main Streetbefore making his striking adaptation of Ladislav Fuks' Spalovač mrtvol (The Cremator, 1968).

Radok, Lustig, and Herz were all survivors of the camps. Herz's later film about Ravensbrück, Zastihla mě noc (I Was Caught by the Night, 1985), while telling the story of a non-Jewish Communist journalist, was actually his attempt to tell the story of Kafka's girlfriend, Milena Jesenská, and also his own experiences. After the Soviet invasion, Weiss and Lustig emigrated to the US and Radok to Sweden.

While Kadár was raised without a personal sense of being Jewish, he also observed that anti-Semitism had only a peripheral presence in the Czech Lands, and that he never experienced discrimination in his professional life. He saw anti-Semitism primarily as a product of Fascism and expected its elimination through social change. After the anti-Semitic nature of the political trials of the 1950s, he recognised its 
continuing reality (although attributing it to 'mistakes'). Following his emigration, the international success of The Shop on Main Streetwas disowned and attributed to Jewish influence.

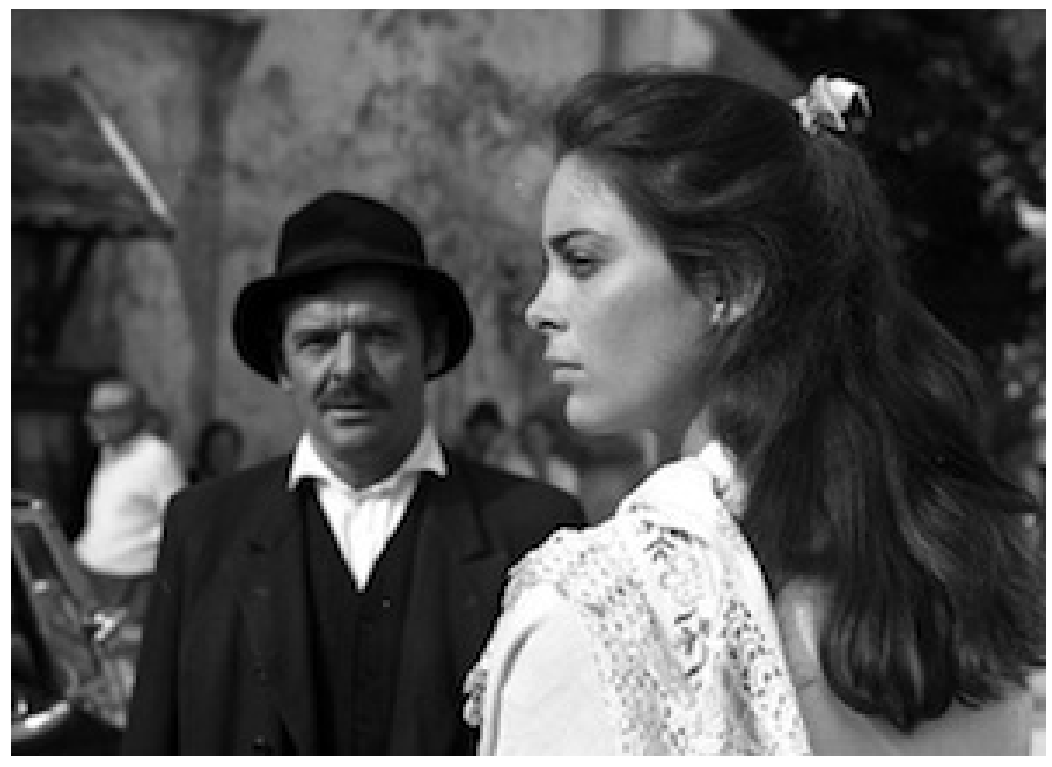

Figure 3: Rade Marković and Paula Pritchett in Adrift (Touha zvaná Anada, 1970/71).

After The Shop on Main Street, it was only natural that he should be offered Jewish topics. According to Macek, he was offered 25 Jewish topics on arrival in the US, most of which didn't interest him. The Angel Levine was actually set up prior to his emigration and Lies My Father Told Me had previously been offered to other directors. If one wants to be pedantic, Mandelstam's Witness can also be considered a 'Jewish' subject, since both Osip and Nadezhda Mandelstam were Jewish and the film is a solo performance by Kamińska.

Kadár's long time commitment to the Communist ideal survived the suppression of the Hungarian Revolution of 1956 but not the Soviet invasion of Czechoslovakia in 1968. One of the themes he wanted to address was the complicity of intellectuals in the Communist deception - how could they have been wrong for 20 years? Yet he observed that it was self-deception by no means restricted to one ideology (as erstwhile disciples of neo-liberalism and neo-conservatism are currently discovering).

His North American films maintain a social and political commitment - to equality, justice, humanism perhaps socialism - ideals which he once thought could be achieved in Czechoslovakia. It's ironic that his last film - Freedom Road - should be based on a novel by the son of Ukrainian Jewish immigrants, who was imprisoned and had his work blacklisted during the McCarthy era. A former member of the US Communist Party, Howard Fast resigned in 1956 following Khrushchev's secret speech exposing the crimes of Stalinism.

The great value of Macek's book is that it focuses attention again on a director who made a major contribution to Czech, Slovak, and world cinema and whose work anticipated that of the Czechoslovak New Wave, and whose English language films seem to have, through a combination of ill luck and his early death, almost become films maudits. However, Adrift, The Angel Levine, Lies My Father Told Me, and Freedom Road are being rediscovered by new audiences and all have their supporters. There is nothing from either his later or earlier work not worthy of systematic re-evaluation.

Macek's book is extensive, and almost contains too much material. I don't recall reading a book and spending so much time on the end notes (which are fascinating in themselves). The notes from Kadár's AFI lectures and the extracts from letter exchanges between Jiří (George) Voskovec in New York and Jan Werich in Prague are particularly useful. The translation clearly presented a somewhat daunting task and is not without awkwardness and linguistic errors. The problem here is that the book does not seem to have had the benefit of an English speaking copy editor - but it is nonetheless an important contribution to the 
reassessment of a significant film maker.

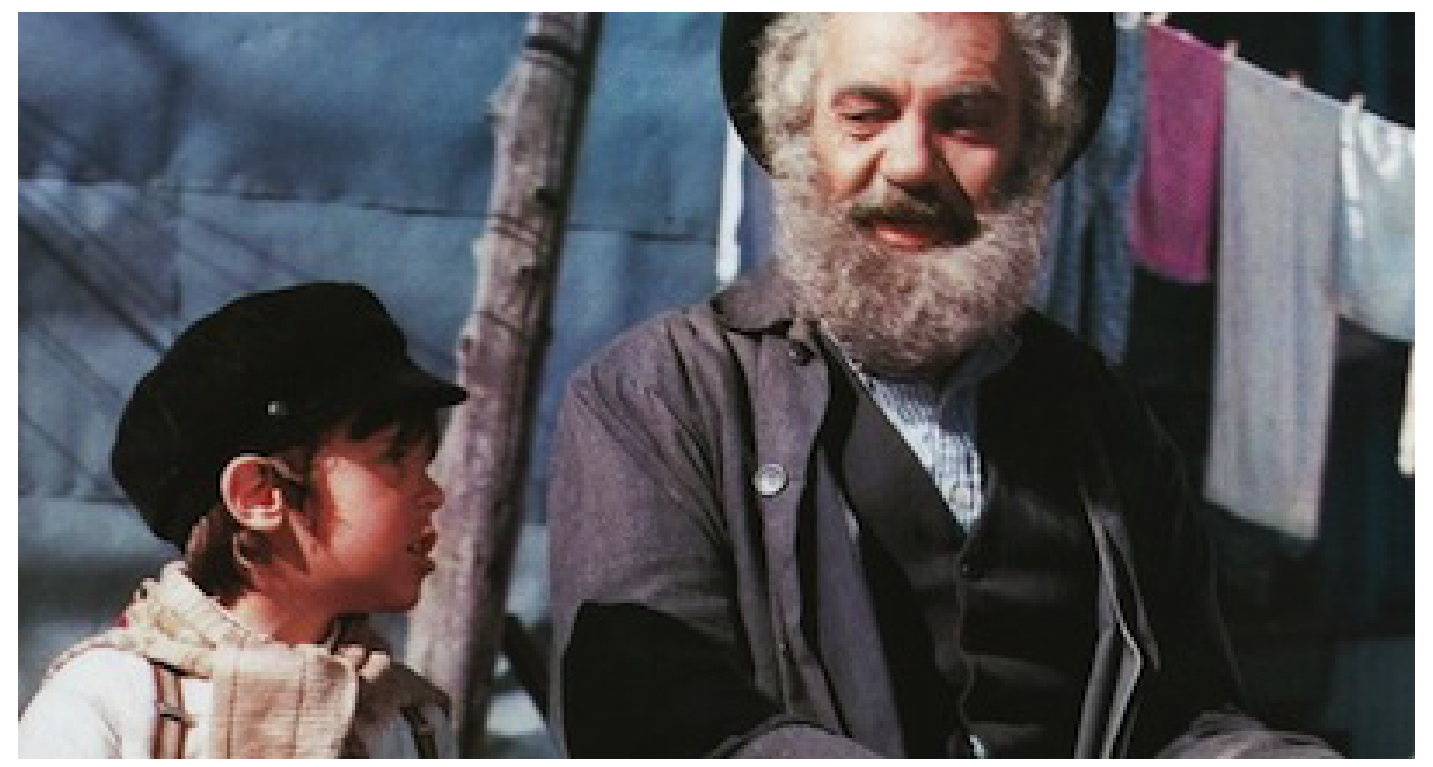

Figure 4: Jeffrey Lynas (l.) and Yossi Yadin in Lies My Father Told Me (1975)

\section{Author Information}

Peter HAMES is a British film historian and film critic. A Honorary Research Associate, Film and Media Studies at Staffordshire University, he has contributed to many journals, including Sight and Sound and Kinoeye. His numerous publications include Dark Alchemy: The films of Jan Švankmajer (ed. 1995); The Czechoslovak New Wave (2005); Czech and Slovak Cinema: Theme and Tradition (2009) and The Cinema of Central Europe (ed. 2004). 